\title{
Murder will Out: Kingship, Kinship and Killing in Medieval Scotland*
}

\author{
Alexander Grant
}

This essay reflects on Jenny Wormald's ground-breaking article, 'Bloodfeud, Kindred and Government in Early Modern Scotland' (1980), ${ }^{1}$ which brilliantly analysed fifteenthand sixteenth-century Scotland's kin-based mechanisms for pacifying feuding, in relation to the public legal system. Essentially, the crown would grant a remission to the perpetrator of illegal violence, including killing, on condition that assythment (compensation) was given to the victim or his kin. It is not only one of the most important articles written on Scottish history, but also - through its wider significance probably the most widely cited; and over thirty years later it reads as powerfully as ever.

Since 1980, work on feuding has multiplied exponentially. Whereas Wormald had to cite only a few dozen studies, nowadays well over a thousand could be mentioned; and her comment, 'greater awareness that feud is a complex business has not resolved all problems of interpretation', now seems a masterly understatement. What, indeed, makes a 'feud'? Long-term fighting across generations, or also short-term retaliation? Only kin-groups, or also other groupings? Only killing, or also non-mortal injury and/or property damage? Are 'bloodfeud' and 'vendetta' different from 'feud', or subsumed within it? Jeppe Büchert Netterstrøm's introduction to a wide-ranging volume examines such issues, giving twenty-six pages on 'definitions and concepts' before considering how to construct 'a comprehensive history of European feuding'. ${ }^{2}$ A 'more flexible' and

* This 'working paper' is the final submitted version of chapter 9 in Kings, Lords and Men in Scotland and Britain, 1300-1625: Essays in Honour of Jenny Wormald, edited by Steve Boardman and Julian Goodare, which is to be published by Edinburgh University Press in June 2014 (see also $<$ http://www.ed.ac.uk/schools-departments/history-classics-archaeology/news-events/events/archivedevents/2012/jennyfest/festschrift>).

1 Past and Present 87 (May 1980), 54-97.

2 Jeppe Büchert Netterstrøm, 'Introduction: The study of feud in medieval and early modern history', in Jeppe Büchert Netterstrøm and Bjørn Poulsen (eds.), Feud in Medieval and Early Modern Europe (Aarhus, 2007), 9-67. Also Susanna A. Throop, 'Introduction: The study of vengeance in the Middle Ages', Paul R. Hyams, 'Was there really such a thing as feud in the high Middle Ages?', and Hyams, 'Neither unnatural nor wholly negative: The future of medieval vengeance', all in Throop and Hyams (eds.), Vengeance in the Middle Ages (Farnham, 2010), 1-4, 151-76, 203-20; and Guy Halsall, 
'broader' definition is preferable, he argues, so that 'long-standing bloodfeuds between Icelandic peasants might then be placed on the same continuum as bloodfeuds between Scottish or Friulian aristocrats as well as the feuds between Franconian noblemen that were not primarily bloodfeuds'. Meanwhile:

Edward Muir has tried to place Renaissance Friuli on a spectrum of European feuding societies. At the one end ... 'might be medieval England, where royal justice stamped out blood feuds earlier than in any other kingdom, and at the other modern Albania, where governments have hardly touched the endemic tribal feuds in the mountains ... Friuli in the Renaissance came closer to the Albanian than the English end of the spectrum'. It is [Netterstrøm's] opinion ... that an effort to place the feuding societies of medieval and early modern Europe on this sort of spectrum may provide a constructive starting point for further comparison. ${ }^{3}$

That 'England-Albania spectrum' is Jenny Wormald's concept: ${ }^{4}$ so 'Bloodfeud, Kindred and Government' now provides a blueprint for taking the subject forward.

Presumably this would employ the flexible and broad Scottish concept of feud, as defined by the estates in 1598: 'all feuds are one of these three natures, namely: that there is either no slaughter upon neither side, or slaughter upon one side only, or else slaughter upon both sides'. ${ }^{5}$ Thus Scottish 'feud' was not necessarily deadly; it included un-friendliness or enmity - as when the duke of Rothesay's council of 1399 promised 'loyal counsel ... not having eye for feud nor friendship'. ${ }^{6}$ As for length, Keith Brown's analysis of 365 feuds between 1573 and 1625 shows that 75 per cent were shorter than five years, ${ }^{7}$ and Steve Boardman's study of late medieval feuding indicates much the same. ${ }^{8}$ Also, though compensation for death went to the victim's kindred, feuding usually involved 'friends and part-takers' too. ${ }^{9}$

'Violence and society in the early medieval West: An introductory survey', in Guy Halsall (ed.), Violence and Society in the Medieval West (Woodbridge, 1998), 1-45.

3 Netterstrøm, 'Study of feud', 66-7; Edward Muir, Mad Blood Stirring: Vendetta and Factions in Friuli during the Renaissance (Baltimore, Md., 1993), 275.

4 Wormald, 'Bloodfeud', 56-7 (acknowledged by Muir and Netterstrøm).

5 RPS, 1598/6/2 ('nather' in the original; rendered as 'either' in the RPS translation, which I have amended).

6 Ibid., 1399/1/3. Rothesay was lieutenant for his father Robert III. This is the earliest recorded use of the term in Scotland: Dictionary of the Older Scottish Tongue (<http//www.dsl.ac.uk>), s.v. 'fede'.

7 Keith M. Brown, Bloodfeud in Scotland, 1573-1625: Violence, Justice and Politics in an Early Modern Society (Edinburgh, 1986), 277-9. 21\% lasted 2-5 years, 17\% 5-20 years, and only 8\% more than 20 years. Almost half the 253 feuds for which details survive were not mortal (27\% no bloodshed, $22 \%$ just bodily assault).

8 Stephen I. Boardman, 'Politics and the Feud in Late Mediaeval Scotland' (St Andrews University Ph.D. thesis, 1989: <http://hdl.handle.net/10023/504>).

9 Wormald, 'Bloodfeud', 68-71. For individual feuds, Brown, Bloodfeud, chapters 4, 6; Boardman, 'Politics and the Feud', chapters 4, 6-8; Jackson W. Armstrong, "The "fyre of ire kyndild" in the fifteenth-century Scottish Marches', in Throop and Hyams (eds.), Vengeance in the Middle Ages, 51-84. 
Wormald's article, however, is essentially about the pacification of feud - for which she drew upon social anthropology, especially Max Gluckman's 1955 essay 'Peace in the Feud'. ${ }^{10}$ Gluckman argued that fear of feuding powerfully inhibited its unlimited escalation, because as a feud expanded many of the participants came to realise the wider threat, especially to their own interests. Consequently, feuds eventually generated a strong desire for pacification, pressurising the protagonists into ceasing hostilities and agreeing settlements: 'peace in the feud'. Though not unchallenged, ${ }^{11}$ this makes broad sense. And recently the behaviourist Christopher Boehm has proposed a similar argument, highlighting two opposing human instincts: to retaliate - for both affection and honour - when a loved one is hurt or killed; but to compromise and pacify if the wider group's interests are threatened. ${ }^{12}$ However, the consequent ambivalences and dilemmas became increasingly problematic as human groupings became bigger and more complex, making feud pacification far from straightforward: feuds could involve a long series of lethal exchanges'. ${ }^{13}$ Boehm's feud seems less peaceful than Gluckman's.

Another, less functionalist, aspect should be added: the 'holy'. In a study of German justice, the legal/cultural historian Wolfgang Schild argues that pre-Christian Germanic peoples had 'a demonic-magic conception of the world', in which a kin's (mythical) ancestor was a 'demonically holy' figure who bequeathed his holiness to his collective kindred. Consequently, when a kin member was killed, the 'rage that led to vengeance' had three reasons: that the kin's 'holy power' was weakened, which only revenge could rectify; that tolerating the initial killing meant the kin was cowardly, which also stimulated revenge; and that if no vengeance were taken, the dead kinsman might return as a ghost to take it himself, and also to punish negligent relatives (as in Hamlet) ${ }^{14}$ Since the sense of ancestral 'holiness' is another long-established instinct, this adds a significant extra dimension to Boehm's arguments.

However, Boehm's quasi-Weberian statements that collective pacification operated only when 'strong authority at the political centre' was absent, and that kingdoms, as they emerge, 'develop sufficient coercive power ... that feuds can be coercively suppressed by the leader, rather than merely being arbitrated', ${ }^{15}$ might raise eyebrows. Yet, as Rees Davies remarked, 'feud as an organised and recognized institution is largely a phenomenon of the stateless society. ${ }^{16}$ Collective pacification mechanisms are far older than central coercive ones, and form the background against which the latter devel-

${ }^{10}$ Max Gluckman, 'The peace in the feud', Past and Present 8 (Nov. 1955), 1-14; also in his Custom and Conflict in Africa (Oxford, 1955).

11 Brown refers to 'Gluckman's ... sanitised bloodfeud' (Bloodfeud, 2), while Netterstrøm suggests he 'perhaps understat[ed] the violent elements in feuding' ('Study of feud', 9); and see their references to post-Gluckman anthropologists.

12 Christopher Boehm, 'The natural history of blood revenge', in Netterstrøm and Poulsen (eds.), Feud in Medieval and Early Modern Europe, 189-203.

13 Ibid., 200.

14 Wolfgang Schild, 'Penal law as a phenomenon of the history of ideas', in Christoph Hinckeldey (ed.), Criminal Justice through the Ages (Rothenburg, 1981), 30-45, at pp. 39-42.

15 Boehm, 'Natural history of blood revenge', 202-3.

16 R. R. Davies, 'The survival of the bloodfeud in medieval Wales', History 54 (1969), 338-57, at p. 341. 
oped - as in medieval and early modern Europe, when, as Wormald said about Scotland, 'the question of interaction between public and private [feud-based] justice is at its most problematic'. ${ }^{17}$ Her analysis naturally highlighted 'the justice of the feud ${ }^{18}$ in relation to the traditional concept of 'the justice of the state'. But in human history feud justice is age-old, whereas state justice is relatively new. Accordingly, since the 'new' is commonly a bigger factor in change than the 'old', my reflections are angled towards the justice of the state.

\section{I}

In the first half, these reflections are on the wider context - beginning in modern Saudi Arabia. Its legal system applies Islamic shari“ $a$ law, whereby, with deliberate homicide, the victim's head of kin can either impose the death penalty on the perpetrator, or remit it and accept diyya (blood-money). ${ }^{19}$ Thus the justice of the feud still operates which impinged on Western consciousness in 1997 after an Australian nurse, Yvonne Gilford, was murdered there. ${ }^{20}$ Two British colleagues were accused, and confessed in prison; one was sentenced to death, the other to 500 lashes. Westerners' reactions were mixed. Some (favouring the death penalty) accepted Saudi justice; but many vehemently condemned the judgement because the confessions appeared forced. That point was technically irrelevant under the Saudi system, however - and the only way to prevent the execution was for Gilford's brother to accept diyya. He initially refused, ${ }^{21}$ but was persuaded to agree, and $\$ 1.2$ million (c.£750,00o) blood-money was paid, allegedly by British defence contractors. The execution and the lashes were cancelled, and the defendants were released in 1998.

The case highlights that fundamental instinct for revenge. Gilford's mother said 'murder the nurses if they murdered my daughter', ${ }^{22}$ and her brother's wife wished 'the killers should go through what my sister-in-law went through'. ${ }^{23}$ This attitude is unsurprising: the second quotation is from a newspaper article examining how, across the West, 'the appeal of retribution is increasing, not in the style of the vendetta ... but along the more limited Biblical lines of an eye for an eye'. ${ }^{24}$ Thus, in a sense, the state

${ }^{17}$ Wormald, 'Bloodfeud', 57.

${ }^{18}$ Ibid., 56ff. (used 27 times in all); a preferable formulation to Gluckman's 'peace in the feud'.

19 Rudolph Peters, Crime and Punishment in Islamic Law (Cambridge, 2005), 38-53, 142-90.

${ }^{20}$ Robert J. Meadows, What Price for Blood? (San Francisco, Calif., 2000); C. R. Pennell, 'Law as a cultural symbol: The Gilford murder case and the presentation of Saudi justice', International Journal of Human Rights 10 (2006), 121-42; Hossein Esmaeili and Jeremy Gans, 'Islamic law across cultural borders: The involvement of Western nationals in Saudi murder trials', Denver Journal of International Law and Policy 28 (1999-2000). The Times Digital Archive also provides a useful account (search for 'Gilford' +'Parry'+'McLaughlan' between Dec. 1996 and June 1999).

${ }^{21}$ Though opposing the death penalty, if the defendant were guilty he wanted her punished, preferably by a long prison sentence - which was not possible under shari'a law.

${ }^{22}$ Pennell, 'Law as a cultural symbol', 135, citing Daily Mail, 23 Aug. 1997.

23 Jack O'Sullivan, 'Wanted: but dead or alive?', Independent, 4 June 1997: <http://www.independent.co.uk /news/1254029.html>, accessed 1 June 2013).

${ }^{24}$ Ibid.: highlighting the USA's 'Federal Victims and Witness Protection Act', 1982, by which increasingly 
has replaced the kin-group as the agency of retributive punishment (often too lenient for victims' families). However, in Saudi Arabia the prosecutor is the victim's head of kin, not a state official. Also, though judges determine whether the accusation is valid, if it is, the accuser determines the accused's fate: diyya or death. That kindred role is typical of feud justice, but the state is not excluded: it is there in an enabling capacity, and has one executive function, for if diyya is refused, a public executioner carries out the death sentence. ${ }^{25}$ So the state could be seen as employing and maintaining the justice of the feud, under shari'a law; there is no conflict between 'state' and 'feud' justice.

Now, shari'a law derives from the Qur'an (seventh century) and Hadiths ('traditions'; ninth century), as interpreted by scholars over subsequent centuries, and the continuities are strong in Saudi Arabia. ${ }^{26}$ Diyya originates in one passage in the Qur'an enjoining compassion instead of eye-for-eye retaliation, and another in the Hadiths indicating that a man's blood-money should be 100 camels. ${ }^{27}$ That is still the Saudi Arabian benchmark - and in 2011 diyya for deliberate homicide was raised from 110,000 ryals to 400,000 (c.£70,000) because of inflation in camel prices. ${ }^{28}$ Saudi blood-money, therefore, represents more than a millennium of continuity - back to the era of Anglo-Saxon wergeld and Gaelic cró. ${ }^{29}$ The standard view is that diyya was introduced to limit feuding: "with the advent of Islam, this institution of revenge was drastically modified' ${ }^{30}$ That probably exaggerates, because the concept is pre-Islamic; $3^{31}$ but shari ${ }^{\prime} a$ law did institutionalise it, ${ }^{32}$ producing a process that can be regarded as having been brought about by the earthly rulers (Muhammad and subsequent caliphs) of a theocratic state, who by incorporating 'peace in the feud' within Islam also harnessed the sense of the 'holy'. Thus we can see the justice of the state impacting on that of the feud during the early Middle Ages, in a way that operated throughout the Islamic world and still does in Saudi Arabia - which, in terms of Wormald's spectrum, is surely right in the middle.

We now shift to Europe, initially the Balkans. Albania is on the spectrum's edge: the horrific feuding that still occurs there is not about order and stability [but] about

frequent 'victim impact statements', generally demanding a retaliatory death penalty, are presented to the court after an accused is found guilty (note that in the UK such statements do not influence sentencing).

${ }^{25}$ Peters, Crime and Punishment, 30-2, 36-7; in the Gilford case this received great press attention.

${ }^{26}$ Ibid., 6-68, 148-53.

${ }^{27}$ Qur'an, 5.45; Hadith Sahi-al-Bukhai, 9.83.36. For early diyya, Lahcen Daaï, 'Le prix du sang (diya) au premier siècle de l'Islam', Hypothèses (2006/1), 329-42.

${ }_{28}$ Arab News, 10 Feb. 2010 and 6 Sept. 2011: <http://www.arabnews.com/node/336788 and .../390060>, accessed 1 June 2013. That is for killing a Muslim male; for a female Muslim, or a Christian of either gender, it is only half.

${ }^{29}$ With payments in livestock, the animals bred and thus provided lasting income. As a Saudi economist stressed, diyya in camels was a long-term investment for the deceased's dependants; but SR40o,0oo would be spent before a victim's children reached maturity: Arab News, 25 Sept. 2011: <http://www .arabnews.com/node/392359>, accessed 1 June 2013.

30 Peters, Crime and Punishment, 40.

${ }^{31}$ Daaït, 'Le prix du sang', 331-2.

${ }^{32}$ See ibid., 332. 
honour', and there is 'no government impact'. ${ }^{33}$ That also applied to neighbouring Montenegro and Kosovo until the twentieth century. However, feuding was mostly limited to their mutual mountainous borderlands, which from the fifteenth century harboured opponents of Ottoman conquest who in 'state' terms were outlaws. ${ }^{34}$ These operated their own feud justice, following a law-code (Kanun) attributed to the antiOttoman leader Lekë Dukagjini (1410-81), which 'became a major symbol of Albanian identity' and still operates nowadays. ${ }^{35}$ Though it included blood-money, that was commonly rejected as dishonourable, and the provisions for Mosaic life-for-life vengeance were preferred and exalted - presumably reflecting hostility to Islam, though aspects of the 'holy' also come to mind. Consequently, the factors which for Gluckman and Boehm militate against extensive, enduring feuding did not operate effectively. In the stateless Albanian, Montenegrin and Kosovan highlands, there was (and in Albania still is) little 'peace in the feud'.

The Balkans were hardly typical, however. What of the heart of Europe, the once Germanic/Frankish territories? Germanic feuding and blood-money were famously described by Tacitus, ${ }^{36}$ and analysed almost as famously by J. M. Wallace-Hadrill in his 'Bloodfeud of the Franks', which applied Gluckman's concept to history for the first time. ${ }^{37}$ Moreover, in 789 Charlemagne prohibited all killings including those of vengeance - 'the earliest piece of legislation against feud' ${ }^{38}$ - and added in 802 that if killing did happen, compensation must be immediately offered and accepted; royal officers maintained both laws. ${ }^{39}$ In the Carolingian Empire as in the Islamic, the state was becoming involved in feud justice.

After the Carolingian Empire collapsed, the parallel was not sustained, especially in what became the German empire. Here, roughly speaking, there were three basic trends: at the top, central authority faded as imperial dynasties came and went; at the

33 Wormald, 'Bloodfeud', 56-7. From the later 1960s, tough action by the Communist regime greatly reduced bloodfeud, but it has re-emerged significantly since 1991: Mentor Mustafa and Antonia Young, 'Feud narratives: Contemporary deployments of kanun in Shala Valley, northern Albania', Anthropological Notebooks 14 (2008), 87-197, at pp. 88-90; Tanya Mangalakova, The Kanun in present-day Albania, Kosovo, and Montenegro (Sofia, 2004: <http://www.imir-bg.org/imir/reports/The_Kanun .pdf >), 3. For Albanian bloodfeud in general, Margaret Hasluck, The Unwritten Law in Albania (Cambridge, 1954), 219-60.

34 Mustafa and Young, 'Feud narratives', 87-9; Christopher Boehm, Blood Revenge: The Enactment and Management of Conflict in Montenegro and other Tribal Societies (2nd edn., Philadelphia, Pa., 1986), 41-5.

35 Mangalakova, Kanun in Albania, 2-3.

36 'It is an obligation to take over the father's or kinsman's feuds (inimicitias) and friendships (amicitias). But feuds do not go on with no reconciliation. In fact, even homicide can be atoned for with a fixed number of cattle or sheep. The whole family receives this compensation. This is an advantage for the community, since feuds are dangerous where freedom exists'. Tacitus, Germania, c. 21: from Tacitus, Agricola and Germany, ed. and trans. Anthony R. Birley (Oxford, 1999), 48.

37 First published in Bulletin of the John Rylands Library 41 (1959), 459-87; reprinted in J. M. WallaceHadrill, The Long-Haired Kings (London, 1962).

${ }^{8}$ J. M. Wallace-Hadrill, Early Germanic Kingship in England and on the Continent (Oxford, 1971), 107-8.

${ }^{39}$ Admonitio Generalis, 789, c. 67; Capitulary (at Aachen), 802, c. 32. English versions in P. D. King (trans.), Charlemagne: Translated Sources (Lambrigg, 1987), 216, 240-1. 
middle, regional duchies and counties achieved semi-independence, but often fragmented through accidents of inheritance; and at the lower, an expanding knightly class became increasingly prominent. ${ }^{40}$ South and south-west Germany finished up as a 'geopolitically highly fragmented area, with ... puny territorial states [and a] kaleidoscopic jumble of ill-defined, intermingled and competing jurisdictions' $;^{41}$ and it was not much better elsewhere. General law-codes existed, especially the Sachsenspiegel (from the thirteenth century), ${ }^{42}$ but little direct overall authority. The emperors did get lords to make regional peace-agreements (Landfrieden), which generally broke down; and princely hostility thwarted Frederick III's empire-wide Landfried of $1465 .{ }^{43}$ In practice, the intermingled jurisdictions made legal dispute-settling virtually impossible: 'each party to a dispute always claimed to have justice on its side, whereas no single supreme institution existed which bindingly defined the law'. ${ }^{44}$ That puts Germany fairly close to Albania on Wormald's spectrum - and of course stimulated feuding.

German feud research, however, has taken a Sonderweg. ${ }^{45}$ Since 1939 , Otto Brunner's Land und Herrschaft has been fundamental; ${ }^{46}$ but that was little known elsewhere until the English translation, 'Land' and Lordship, appeared in 1992, ${ }^{47}$ possibly because of its difficult German, ${ }^{48}$ but also possibly because Brunner, an enthusiastic National Socialist, ${ }^{49}$ said it studied the "political concepts of the Third Reich' ${ }^{50}$ However, as Benjamin Arnold commented, 'it would be hard to detect that his scholarly exposition ... [has] been tainted by false notions about the historical driving forces of Volk and Führung.$^{51}$ We may never know; but Brunner's arguments set the

${ }^{40}$ What follows derives from F. R. H. du Boulay, Germany in the Later Middle Ages (London, 1983), chapters 2-4; John Watts, The Making of Polities: Europe, 130o-15oo (Cambridge, 2009), 59-66, 188-91, 301-7, 352-5; Benjamin Arnold, Princes and Territories in Medieval Germany (Cambridge, 1991); and Tom Scott, 'Germany and the Empire', in The New Cambridge Medieval History, vol. VII, c.1415-c.15oo (Cambridge, 1998), 337-66.

${ }^{41}$ Hillay Zmora, The Feud in Early Modern Germany (Cambridge, 2011), 49.

${ }^{42}$ The Saxon Mirror: A Sachsenspiegel of the Fourteenth Century, trans. Maria Dobozy (Philadelphia, Pa., 1999).

43 Du Boulay, Germany, 76-3; Scott, 'Germany and the Empire', 358-9; Watts, Making of Polities, 62, 101-2, 190, 303, 354; and F. R. H. du Boulay, 'Law enforcement in medieval Germany', History 63 (1978), 345-55.

44 Zmora, Feud, 40.

45 Netterstrøm, 'Study of feud', 20-8 (on 'The Sonderweg of German feud research').

${ }^{46}$ Land und Herrschaft: Grundfragen der territorialen Verfassungsgeschichte Südostdeutschlands im Mittelalter (Vienna, 1939).

47 'Land' and Lordship: Structures of Government in Medieval Austria, trans. Howard Kaminsky and James Van Horn Melton (Philadelphia, 1992); translating the fourth, heavily revised, edition (Vienna, 1959), in which Österreichs replaced Südostdeutschlands in the title.

${ }^{48}$ Ibid., p. xiii.

49 Peter N. Miller, 'Nazis and Neo-Stoics: Otto Brunner and Gerhard Oestreich before and after the Second World War', Past and Present 176 (Aug. 2002), 144-86, at p. 157: in 1943 'the officer to whom Brunner reported' was SS-Obergruppenführer Ernst Kaltenbrunner, head of the Reich's Security Service.

${ }^{50}$ Brunner, Land und Herrschaft (1st edn.), 512; cited by Miller, 155.

${ }^{1}$ Benjamin Arnold, 'Structures of medieval government and the thought-world of Otto Brunner (18981982)', Reading Medieval Studies 20 (1994), 3-12, at p. 9. But Miller, 'Nazis and Neo-Stoics', stresses 
agenda for the German-speaking world, and are crucial here.

Brunner rejected state-oriented history, employing a bottom-up approach to show what was really going on. He focused on Austria's districts and provinces, to which he applied the term Land. This was not just territorial:

Land was a legal idea ... nearer to 'district' in one of its original senses as a juridical dimension in which, in the medieval milieu, all rights, authority, and law added up to a shared endeavour partly to do with administering the law courts, partly to do with the defence of the land, and partly allowing for selfdefence within the land. ${ }^{52}$

It is the territory of Landfrieden, and not unlike the English county community. Brunner derived it from the Germanic past, when 'Civitas, tribe and Land were associations of arms-bearing men ... able to fight for their rights' ${ }^{53}$ Such fighting could be done either in a court, or if (as was often the case) that was unsatisfactory, through force of arms - in other words feud, which 'was as integral to medieval political life as war is to the modern state'. ${ }^{54}$

But Brunner's feud was purely 'knightly', and excluded bloodfeud:

The Middle Ages distinguished ... between blood vengeance, that is, mortal enmity, and the knightly feud with its 'challenge'. The former could be employed by anyone ... On the other hand the knightly feud was reserved to the nobility and seigneurial proprietors of similar status ... The knightly feud could be employed to settle any conflict, so that even the most trivial legal dispute could serve as an excuse for declaring a feud. ${ }^{55}$

This 'knightly feud' did not involve vengeance, and was legitimate if formally declared - as confirmed by Charles IV's 'Golden Bull' of 1356, which prohibited attacks 'under the pretext of a feud, with arson, robbery or plunder, unless the feud has been announced publicly ... three days in advance'. ${ }^{56}$ The legitimation, however, did not apply to killing, and while 'the killing of one's opponent' and 'honest homicide' are recorded 'often enough',

that the removal of Nazi concepts from the 1959 edition obscures the argument (p. 154); that in 1939 Brunner declared, 'Not the state, nor culture, are for us today the object of history, but rather Volk and Reich' (p. 155); and that 'Fernand Braudel was right to be suspicious of Brunner's motives' (p. 158; Land und Herrschaft has never been translated into French).

${ }^{2}$ Arnold, 'Structures of medieval government', 4-5. Because Brunner used Land in a technical sense, inverted commas are used in citations of the English title.

${ }^{53}$ Brunner, 'Land' and Lordship, 17.

54 Ibid., 90.

55 Ibid., 16.

${ }^{56}$ Quoted in Zmora, Feud, 34, in the context of Baron Georg von Puchheim's 1453 letter to Emperor Frederick III telling him, 'I want to be enemy of Your Grace's land and people, and wherever I encounter your servitors and subjects, I will cause them damage'. 
in knightly feuds the killing of one's opponents was something rather to be avoided. For one thing, it was not exempt from the vengeance of the victim's friends and relatives - that is, from blood vengeance and blood feud. And for another, even though it was legally recognised as long as 'enmity' existed between the parties, it nevertheless went against the purpose of the feud, which was to rectify an injustice, not to destroy the other party. ${ }^{57}$

Killing in 'knightly feud' broke the rules, and the killer's peers would turn against him - making it counter-productive. But otherwise feuding had a very wide scope. 'Injustice' was any slight to knightly (and hence aristocratic) honour; and any member of the knightly class could declare feud against any other, even a territorial prince or the emperor. ${ }^{58}$

The commonest quarrels, however, were among those in frequent contact, and the typical feud occurred within a Land. The aim was to make an opponent redress the 'injustice' by damaging his lordly and economic status through attacks on his dependent peasantry. Thus the peasants were 'most affected by feuds ... the loss of harvest, cattle, clothing, and household furnishings was bad enough, while the burning down of whole villages caused losses that were irreparable ${ }^{59}$ - and peasants were often killed. But that was how the world worked: 'feud [was] an evil, but one as unavoidable as crop failures and famine'..$^{60}$ The affected peasantry had either to suffer or to abandon their lords - the purpose of the exercise - and fatalities were simply collateral damage.

'Land' and Lordship 'has become a veritable battleground', ${ }^{61}$ and consequently 'German historiography exceeds by far any other national historiography as to the quantity of feud studies produced ${ }^{62}$ - all broadly within Brunner's conceptual frame-

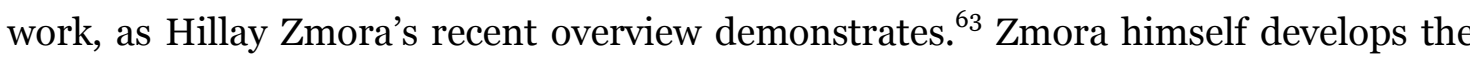
analysis significantly. One instance is his concept of 'inimical intimacy': ${ }^{64}$ Brunner located feuding within the Land, but for Zmora it is even more local. Feuds mostly derive from neighbourly friction - and those who fail to counter a neighbour's hostility are despised by others. Hence Zmora stresses proximity more than honour. Also, most importantly, he brings in a higher political level, highlighting rivalries and conflicts among the German princes - who used, manipulated and stimulated knightly hostilities to gain advantages against their own princely rivals. This gives a top-down dimension to German feuding after all, and leads Zmora to connect it with 'state-building', albeit at the princely rather than the imperial level. ${ }^{65}$

57 Brunner, 'Land' and Lordship, 68.

${ }^{8}$ As in note 56, above.

59 Brunner, 'Land' and Lordship, 88-9.

${ }^{60}$ Ibid., 91, quoting a tenth-century text.

${ }^{61}$ Zmora, Feud, 9.

${ }^{62}$ Netterstrøm, 'Study of feud', 22.

${ }^{63}$ Zmora, Feud, 1-28.

${ }^{64}$ Ibid., 50 ff., $77 \mathrm{ff}$.

${ }^{65}$ Ibid., chapters 5-6, based largely on Franconia, his own research area, rather than Brunner's Austria; 
Zmora's insights are fascinating, with European, not just German, relevance; yet his work is still within Brunner's 'knightly feud' parameters. That is a general point: as Netterstrøm chides, the 'self-sufficiency of feud studies probably explains why German feud research has neither significantly obtained the foreign anthropological and historical literature on feud nor compared the German feud system to the feuding societies of, say, Icelandic peasants or Scottish aristocrats' ${ }^{66}$ Comparisons with Scotland are certainly instructive. Two immediate thoughts are that Scottish feuding often had 'no slaughter upon neither side'; ${ }^{67}$ but that German knightly quarrels could involve killing, and even (as Brunner admitted) bloodfeud:

Killing for revenge ... was something quite different ... The murderer was peaceless vis-à-vis the friends and relatives of his victim, and could therefore be killed out of hand unless an atonement intervened ... Even among the nobility and others who had the right to feud, and whose feuds were mostly of the ordinary sort, the blood feud was not unknown. ${ }^{68}$

Thus it is not that late medieval German elites did not have bloodfeuds; it is that (because of Brunner's approach) these appear not to have received in-depth study. Yet the Sachsenspiegel lawcode that was followed for centuries treated wergeld, a major concomitant of bloodfeud, as current; ${ }^{69}$ and actual wergeld payments by killers are recorded in seventeenth-century Holstein. ${ }^{70}$ Surely, therefore, compensation for both 'honest homicide' in knightly feuds and killings in bloodfeud was required - which suggests German parallels with all types of Scottish feuding.

As for the anthropological issue, 'peace in the feud' existed in early medieval Germany, upheld by central power; but when central power diminished, we might expect feuding to have intensified. However, if most significant quarrels occurred within coherent group structures (Brunner's Land, Zmora's neighbourhood), then, in the absence of effective external authority, group pressures to avoid or settle feuding would no doubt have increased, as would individual and collective fears of its disastrous effect. The collective group response would presumably have been to create a means of settling elite disputes honourably but with the least possible violence - as Brunner implicitly argued. ${ }^{71}$ That is surely what the knightly feud was about: letting landowning neighbours quarrel dramatically and satisfactorily, without threatening

also Hillay Zmora, State and Nobility in Early Modern Germany (Cambridge, 1997).

${ }^{66}$ Netterstrøm, 'Study of feud', 22-3.

${ }^{67}$ Above, at note 5. Two examples are the Angus-Dalkeith feud in 1399 and the Hepburn-Hume one in the mid-1440s: Michael Brown, The Black Douglases: War and Lordship in Late Medieval Scotland, 1300-1455 (East Linton, 1998), 88-91, 94; Armstrong, 'Fyre of ire kyndild', 64-72.

68 Brunner, 'Land' and Lordship, 68.

${ }^{69}$ Dobozy (trans.), Saxon Mirror, 20-4, and ad indicem.

${ }^{70}$ Bertha S. Phillpotts, Kindred and Clan in the Middle Ages and After (Cambridge, 1913), 125-46, esp. pp. 138-9. Holstein is the only part of the Empire included in Phillpotts's book.

71 Brunner, 'Land' and Lordship, 68. 
each other's death. So, while honour could be ostentatiously upheld, the factors that made feud so fearsome were removed. I suggest, therefore, that in later medieval Germany the 'bloodfeud of the Franks' was 'sanitised' or emasculated, ${ }^{72}$ allowing elites to indulge in frequent non-mortal, honourable and legitimate conflicts - in which ordinary people suffered most.

Meanwhile, what was going on in the western remnant of the Frankish Empire, namely France? Much the same, according to Howard Kaminsky. ${ }^{73}$ A translator of Land und Herrschaft, he also dismisses state-focused history as anachronistic, focuses on Land-like 'modules of lordship', emphasises 'the noble feud', and argues that it was fundamental: 'just as one cannot imagine the modern state tolerating a right to feud, so we cannot imagine the medieval state without it'. ${ }^{74}$ Yet while in principle noble/knightly feud ('guerre privée', or private warfare, in French terminology) might have been the same in France and Germany, ${ }^{75}$ royal power was not. It grew significantly in thirteenth- and early fourteenth-century France, and though there were huge political crises later, the basis of French crown authority survived and royal power was reconstructed. But, as Graeme Small stresses, 'the picture ... is necessarily more complex than the roller-coaster, single-track story of the monarchy's "progress"'. We should think instead of a 'plurality of powers ... and consider the interactions between them: kings and princes, of course, but also nobles, churchmen, municipal authorities and peasant communities' ${ }^{76}$ Much of the royal-noble interaction involves the noble feud, which 'continued in France throughout [and beyond] the later Middle Ages'; ${ }^{77}$ and here I consider the crown, or state, response.

From Louis IX (1214-70) to Charles V (1364-80), some thirty ordinances prohibiting private warfare were issued, to little general effect; ${ }^{78}$ in southern France

72 'Yet despite the apparent rule of force, a feature of the German Fehde was the frequent weakness of those who pursued it': Du Boulay, 'Law enforcement in medieval Germany', 346.

73 Howard Kaminsky, 'The noble feud in the later Middle Ages', Past and Present 177 (Nov. 2002), 55-83.

74 Ibid., 57-8.

75 Except that accounts of French private war show that there was no bar to killing; and see Justine Firnhaber-Baker's explanation of why she prefers 'war' to 'feud: 'Jura in Medio: The settlement of seigneurial disputes in later medieval Languedoc', French History 26 (2012), 441-59, at pp. 445-6.

${ }^{76}$ Graeme Small, Late Medieval France (Basingstoke, 2009), 3; from Lewis's phrase, 'the pluralistic nature of power distribution': P. S. Lewis, 'Reflections on the role of royal clientèles in the construction of the French monarchy', in N. Bulst et al. (eds.), L'état ou le roi (Paris, 1996), 51-68, at p. 55. The 'plurality of powers' is a recurrent theme in Small's discussion of the political aspects of late medieval French history. See also David Potter (ed.), France in the Later Middle Ages, 1200-150o (Oxford, 2003), and the chapters on France in The New Cambridge Medieval History, vol. VI, c.130o-c.1415 (Cambridge, 2000), and vol. VII, c.1415-c.150o (Cambridge, 1998).

77 Kaminsky, 'Noble feud', 40. See, e.g., Robin Harris, Valois Guyenne (Woodbridge, 1994), 137-42; Stuart Carroll, 'The peace in the feud in sixteenth- and seventeenth-century France', Past and Present 178 (Feb. 2003), 74-115; and Stuart Carroll, Blood and Violence in Early Modern France (Oxford, 2006), which has valuable material on the fifteenth century in the introduction and first chapter.

${ }^{78}$ Most prohibited it during times of international war, but at least one per reign banned it altogether: Justine Firnhaber-Baker, 'Seigneurial war and royal power in later medieval southern France', Past and Present 208 (Aug. 2010), 37-76, at pp. 51-3; and, more generally, Raymond Cazelles, 'La réglementation royale de la guerre privée de Saint Louis à Charles V et la précarité des ordonnances', Revue 
'local wars were just as common ... as in the feud-friendly Empire'. ${ }^{79}$ Yet the ordinances did at least assert royal antipathy to private warfare. Also, both Richard Kaeuper and Justine Firnhaber-Baker show that while they did not prevent that from breaking out, once it happened individuals could be prosecuted for breaching them. ${ }^{80}$ But the 'plurality of powers' also applied: noble claims to a right to private warfare had considerable effect, ${ }^{81}$ and so such prosecutions succeeded only in areas under direct royal jurisdiction. ${ }^{82}$

However, from Philip IV's reign (1285-1314) other strategies were employed. First, 'interaction between royal and noble powers' was utilised: 'royal officials allowed and indeed themselves engaged in a range of extra- and quasi-judicial negotiations with warmakers', especially by acting as high-status honest brokers to persuade warring parties to compromise and make peace. ${ }^{83}$ Second, a direct means of responding to feuding anywhere, irrespective of jurisdictions, was developed: that of bringing one of the parties into the king's special peace. ${ }^{84}$ To attack someone within that peace was tantamount to attacking the king himself - always illegal no matter where the offender lived. This nullified the plurality of powers, since everyone in the kingdom was the king's subject. Providing 'safeguards' for threatened individuals, therefore, helped combat private warfare. It was not infallible: a safeguard might be obtained by the aggressor, or by both sides, or could be ignored - though that was risky. ${ }^{85}$ Safeguards were simply based on the king's age-old right to protect his friends; ${ }^{86}$ but through that traditional power, French crown authority extended into the world of the feud.

Third, that also happened via letters of remission granting royal pardons, which survive from 1304 on. Though these were criticised both then and now 'for allowing thieves and murderers to escape with impunity', ${ }^{87}$ Claude Gauvard's magisterial analysis of 7,500 of the remissions that the royal chancery issued throughout the kingdom between 1364 and 1515 paints a very different picture. ${ }^{88}$ They went to all social classes,

historique de droit français et étranger, 4th ser., 38 (1960), 530-48.

79 Firnhaber-Baker, 'Seigneurial war', 46; also Firnhaber-Baker, 'Jura in Medio', 444-7.

${ }^{80}$ Richard W. Kaeuper, War, Justice and Public Order: England and France in the Later Middle Ages (Oxford, 1988), 239-60; Firnhaber-Baker, 'Seigneurial war', 51-7 (superseding Cazelles's and Kaminsky's interpretation); Firnhaber-Baker, 'Jura in Medio', 447-9.

${ }^{81}$ Firnhaber-Baker, 'Seigneurial war', 55.

${ }^{82}$ Ibid., 63-7.

83 Firnhaber-Baker, 'Jura in Medio', 450-5 (quotation from p. 451).

${ }^{84}$ Firnhaber-Baker, 'Seigneurial war', 69-74; also Kaeuper, War, Justice and Public Order, 235-60.

85 As illustrated by the execution of the early fourteenth-century Gascon lord Jourdain de l'Isle. See the very different accounts in Kaminsky, 'Noble feud', 69, and Kaeuper, War, Justice and Public Order, 226; plus Joseph Kicklighter's fascinating full-scale study, 'The nobility of English Gascony: The case of Jourdain de l'Isle', Journal of Medieval History 13 (1987), 327-42.

${ }^{86}$ Firnhaber-Baker, 'Seigneurial war', 70-1.

${ }^{87}$ Firnhaber-Baker, 'Jura in Medio', 457.

${ }^{88}$ Claude Gauvard, 'De grâce especial': Crime, état et société en France à la fin du Moyen Âge (1991; 2nd, 1-volume, edn., Paris, 2010), esp. 703-806, 896-952. For a brief version of the most striking part of her argument, see Claude Gauvard, 'Grâce et exécution capitale', Bibliothéque de l'École des chartes, 
though nobles are over-represented proportionally. Fifty-seven per cent involved homicides, of which the vast majority ( 85 per cent) were acts of vengeance - but only about a third were triggered by previous killing, while two-thirds avenged oral or physical insults. ${ }^{89}$ Thus, while l'honneur blessé was a crucial motive, life-for-life killing was not prevalent. Gauvard attributes that to the letters of remission, ${ }^{90}$ arguing that a predominant sense of honour fostered wide tolerance of violent responses to insults, but that after the initial hot-blooded action the priority was to prevent further killing: hence the remissions. ${ }^{91}$ And being acts of royal grace and mercy outside and above formal legal processes, ${ }^{92}$ they, like safeguards, were available to anyone irrespective of jurisdictional technicalities.

But what of the dead victim's kin, who would want their own revenge? Because remission letters narrate the offender's story, Gauvard's analysis is almost entirely from that standpoint. However, one brief passage shifts the focus:

Whatever the process adopted for restoring the peace, an accord was always necessary in order for the king to be able to legitimately grant his remission. The clause that limited royal grace, the only one that might be formulated, provided that 'satisfaction is to be made to the party if not [already] made'. It is present in $90 \%$ of the letters: it is therefore a clause that could not be got round. ${ }^{93}$

The procedure for bestowing royal grace is also important. ${ }^{94} \mathrm{~A}$ killer seeking remission had to obtain chancery authorisation, get his letter properly written, submit it for royal approval, pay a fee - and then present it to the relevant local court, where its accuracy would be investigated, ideally before his victim's kin, who could challenge it and demand damages. Only then, if all went well, would the letter be formally ratified. The court hearing was vital, but it judged not the killer himself but the narrative in his letter and, especially, the satisfaction of his victim's kin - to assure the king that his exercise of royal grace was deserved. This is the most significant way whereby the late medieval French crown came, by extra-judicial means, to exert state authority over the

153 (1995), 275-90. The 7,500 remissions consist of all 3,752 issued between 1380 and 1424 plus a full sample of the rest.

${ }^{89}$ Gauvard, 'De grâce especial', 242 (table 8), 756 (table 41; my extrapolation), and in general chapter 16 ('L'honneur blessé').

${ }^{90}$ Ibid., within chapters 17 ('La Vengeance'), 18(2) ('Meutres et homicides'), and 20 ('Pardonner et punir'); esp. 778-9, 797-9, 940-4.

91 Best summed up in Gauvard, 'Grâce et exécution capitale', 218: 'the royal chancery had every facility to grant the remission - a remission which stops vengeance and precipitates accord between the parties'.

92 Ibid., 277-80, and Gauvard, 'De grâce especial', 907-20 ('Justice et miséricord).

93 Gauvard, 'De grâce especial', 778: 'satisfaccion soit faicte a partie si faite n'est'.

94 Natalie Zemon Davis, Fiction in the Archives: Pardon Tales and their Tellers in Sixteenth-Century France (Cambridge, 1988), 8-14; also Carroll, 'Peace in the feud', 106-8, and Carroll, Blood and Violence, 214-21. 
feud-settlement process - though actual feuding still continued during the early modern era.

Thus, while France and Germany had common roots, the late medieval contrast is striking. Admittedly, that might be due partly to different approaches: if a German study included peasant quarrels and killings, or if a French one dealt only with the knightly classes, it might be less. ${ }^{95}$ Nevertheless, the role of the crown was crucial: the French kings found ways of bypassing jurisdictional problems; the German emperors did not; nor, yet, did the princes (who did not possess 'royal grace'). As for Wormald's spectrum, France can be placed well within the English side - while the relevance of French procedures, especially letters of remission, for any commentary on her 'Bloodfeud' is patently obvious.

We now cross to England, where, to quote Wormald,

before the Norman Conquest public authority had already taken over at least part of the responsibilities of the kin, and where within two centuries after it the bloodfeud itself had been replaced by a concept of crime enshrined in a uniquely comprehensive system of royal justice. ${ }^{96}$

Her summing-up is still valid, though nuanced by recent work. In particular, Paul Hyams's Rancor and Reconciliation softens the distinction between earlier kin-based and later crown-based justice. ${ }^{97}$ Hyams shows that once the latter became predominant (in the thirteenth century), state agency provided an effective and safe way of gaining revenge on an opponent - by getting him condemned either to death, or more commonly to outlawry for fleeing trial (so anyone could kill him). Many of Hyams's 'case narratives' illustrate how English royal justice became an instrument of feud: if you seek revenge and can manipulate the judicial system (or have it manipulated), that becomes a powerful weapon. ${ }^{98}$

The more complex the system, the more it could be manipulated - as in fourteenth- and fifteenth-century England, where numerous conflicts among the landed classes led Kaminsky to apply his concept of 'noble feud' there as well as to France.

${ }^{95}$ Since over $90 \%$ of Gauvard's letters related to non-nobles, the conclusions from these will obscure any noble-specific points. That said, Carroll's analysis in Blood and Violence, which focuses much more on nobles, does not contradict Gauvard's.

96 Wormald, 'Bloodfeud', 57.

97 Paul L. Hyams, Rancor and Reconciliation in Medieval England (Ithaca, NY, 2003); also T. B. Lambert, 'Theft, homicide and crime in late Anglo-Saxon Law', Past and Present 214 (Feb. 2012), 3-43; John G. H. Hudson, 'Feud, vengeance and violence in England from the tenth to the twelfth centuries', in Belle S. Tuten and Tracey L. Billado (eds.), Feud, Violence and Practice: Essays in Medieval Studies in Honor of Stephen D. White (Farnham, 2010), 29-54; Richard L. Keyser, “Agreement supersedes law, and love judgement”: Legal flexibility and amicable settlement in Anglo-Norman England', Law and History Review 30 (2012), 37-88; Daniel Klerman, 'Settlement and the decline of private prosecution in thirteenth-century England, Law and History Review 19 (2001), 1-65.

${ }^{98}$ Hyams, Rancor and Reconciliation, 242-308; and see Brown, Bloodfeud, 44: 'in a feuding society ... the law was simply seen as a weapon with a cutting edge of its own for pursuing violence'. 
Despite errors, he has a point: ${ }^{99}$ English noble and gentry feuding seems to have become more frequent, particularly in the fifteenth century. ${ }^{100}$ Gerald Harriss provides the best explanation. ${ }^{101}$ Most feuding originated in land disputes, which became common because England's increasingly complex land laws not only stimulated claims and counter-claims but also made victory in court near-impossible to achieve. ${ }^{102}$ Instead, disputants used simpler actions of trespass and breach of the peace, hoping to pressurise opponents into out-of-court settlements. And both sides generally obtained support from their lords; so great men were sucked into gentry disputes. Ideally, compromises would be arranged, with reparations where necessary. ${ }^{103}$ Unfortunately, such arbitrated settlements were not absolutely binding, and were often broken. And though appeals could be made to the chancellor, parliament or king, if one party appealed successfully, the other generally objected. Consequently, 'where litigation, lordship, private treaty, or public authority failed, it was likely that one of the parties would resort to force'. ${ }^{104}$ As elsewhere, that meant honourable use of arms in defence of family interests - feuding - which was unlikely to be punished heavily. Inter-family feuds often escalated into local power-struggles, pulling in rival magnates - which could exacerbate the situation, necessitating crown intervention. However, if one side in a conflict was well placed at the royal court or had powerful friends there, crown intervention might not be neutral. The interaction of local and national politics, therefore, could be destabilising: for several historians, indeed, local feuding was a major causal factor in the mid fifteenth-century 'Wars of the Roses'. ${ }^{105}$

This is not unlike Brunner's, Kaminsky's, and especially Zmora's worlds - though England's 'state problem' appears to be too much institutionalised crown authority, not

99 Kaminsky, 'Noble feud', 74-9; though English disputes, like French, do not fit all the Brunner/Kaminsky criteria. He is badly mistaken over the Gloucester-Hereford dispute of 1290, which they claimed was legitimate in the Welsh Marches; see Michael Prestwich, Edward I (London, 1988), 348-50. Also, his statement that 'Edward III still “condoned” the nobles' "right of defiance” in principle' (citing M. H. Keen, The Laws of War in the Late Middle Ages (1965), 232) is wrong: Edward was referring to Aquitaine not England.

${ }^{100}$ Henry VI's reign is the apogee. R. L. Storey, The End of the House of Lancaster (2nd edn., Stroud, 1999), and Ralph A. Griffiths, The Reign of King Henry VI (2nd edn., Stroud, 2004), chapters 7, 20, highlight the local violence. See also J. G. Bellamy, Criminal Law and Society in Late Medieval and Tudor England (Gloucester, 1984) 54-89, for what he called 'gentlemen's wars' (pp. 64, 70, 84).

${ }^{101}$ Gerald Harriss, Shaping the Nation: England, 1360-1461 (Oxford, 2005), 197-202, from which the rest of this paragraph derives. The best account of the criminal justice system is Edward Powell, Kingship, Law, and Society: Criminal Justice in the Reign of Henry V (Oxford, 1989), 23-114; see also Kaeuper, War, Justice and Public Order, 151-60, 174-83, 260-7, and Bellamy, Criminal Law, 54-89.

102 Thus, 'it might even be argued that royal power contributed to disorder and the authority of the crown was a public nuisance': M. T. Clanchy, 'Law, government and society in medieval England', History 59 (1974), 73-8, at p. 78 .

${ }^{103}$ Commonly in 'lovedays': Michael Clanchy, 'Law and love in the Middle Ages', in John Bossy (ed.), Disputes and Settlements: Law and Human Relations in the West (Cambridge, 1983), 47-68, refined by Keyser, 'Agreement supersedes law', 40-4. For arbitration, Edward Powell, 'Arbitration and the Law in England in the Late Middle Ages', TRHS 5th ser., 33 (1983), 49-67, and Edward Powell, 'Settlement of disputes by arbitration in fifteenth-century England', Law and History Review 2 (1984), 21-43.

${ }^{104}$ Harriss, Shaping the Nation, 200.

${ }^{105}$ See note 100, above. 
too little. The best solution was direct royal action - very direct, believed the author of a story about Henry V (1413-22) in the Brut chronicle. A Lancashire and a Yorkshire knight were feuding, and some of their followers were killed. Henry summoned them, and asked on what authority they had made his lieges kill each other. They begged for mercy, whereupon Henry said he had some oysters to eat, and unless they had made peace before he finished, they would be hanged! ${ }^{106}$ They did, of course. The story presumably written later, when feuding was rife - portrayed Henry as the great upholder of justice. Yet the letter of the law was not followed: despite the killings, he pardoned the offenders - but terrified them into not offending again. Edward Powell has illustrated the reality of such flexibility. Under Henry IV (1399-1413) the midlands had suffered from serious disorder and feuding; so in 1414 Henry V sent King's Bench judges there on 'superior eyre'. Some 2,200 persons were indicted for violence, and about 800 stood trial (the rest would have been outlawed). But few were found guilty; most either paid a fine in advance or bought a pardon, and Henry soon pardoned everyone who had been indicted. That looks like serious weakness in one of medieval England's toughest kings - yet, as Powell asks, what else could be done? Those indicted included most of the county elites; had they been imprisoned or executed, local government would have collapsed. ${ }^{107}$ On the other hand, 'the most serious offenders were made to take out recognisances for large sums to keep the peace; for the rest a fine or pardon was sufficient to buy off the king's suit and gain readmission to his peace'. ${ }^{108}$ Those readmitted to the king's peace would have known that reoffending would not be tolerated - surely the Brut's main message.

Henry V's strong personal kingship evaporated under Henry VI (1422-61), and though Edward IV (1461-83) was tougher, his real heir in this respect was Henry VII (1485-1509). Had the oysters story been written about him, the knights would have been put under recognisance, promising in writing to pay a large sum of money if they offended again. All fifteenth-century kings used recognisances to a certain extent, but Henry VII made them 'the linchpin of his entire ruling system'; ${ }^{109}$ hundreds were exacted from men engaging in violent disputes, generally after appearing before Henry himself or his council. That bypassed the formal, clogged-up, law-courts - but in practice was the best way of dealing with troublesome gentry and lords. ${ }^{110}$

Thus the response to feuding by the two most successful fifteenth-century English kings paralleled French rather than German practice. Also, the numerous pardons

\footnotetext{
${ }^{106}$ The Brut, ed. F. W. D. Brie (EETS, 1906-8), ii, 595; Powell, Kingship, Law, and Society, 230-1.

${ }^{107}$ Ibid., 166-94.

108 Ibid., 194.

${ }^{109}$ Sean Cunningham, Henry VII (Abingdon, 2007), 216.

${ }^{110}$ Ibid., 209-33; Sean Cunningham, 'Loyalty and the usurper: Recognizances, the council and allegiance under Henry VII', Historical Research 82 (2009), 459-81; Sean Cunningham, 'Henry VII, Sir Thomas Butler and the Stanley family', in Tim Thornton (ed.), Social Attitudes and Political Structures in the Fifteenth Century (Stroud, 2000), 220-41; and Sean Cunningham, 'The Establishment of the Tudor Regime: Henry VII, Rebellion, and the Financial Control of the Aristocracy, 1485-1509' (Lancaster University Ph.D. thesis, 1995).
} 
recorded in the patent rolls of fourteenth- and fifteenth-century England suggest that royal grace was exercised as frequently as in France; ${ }^{111}$ while English letters of pardon had to be 'proved' in court, when 'any appellant wishing to bring a suit against the recipient of the pardon' was entitled to object. ${ }^{112}$ However, as the word 'appellant' indicates, a simple objection was not enough; it had to be made through a legal 'appeal of felony' - a formal private prosecution - which could win damages, but might be both costly and unsuccessful. ${ }^{113}$ That was obviously much less satisfactory for injured parties than the French system, in which remissions were almost always conditional upon their satisfaction. The reason was, of course, the great development of twelfthand especially thirteenth-century English royal justice ${ }^{114}$ - as a result of which, F. W. Maitland remarked many years ago, the law of wer [wergeld], being no longer applicable if there was felony, perished for lack of sustenance, and the parentes occisi [kinsmen of the slain] were reduced to getting what they could by threats of an appeal'. ${ }^{115}$

Wergeld, indeed, had become 'anathema to English common law' - as Rees Davies commented in regard to Edward I's abolition of the Welsh version, galanas, after conquering the principality of Wales in $1284 .{ }^{116}$ But it must be added that outside the principality, in the Welsh Marches, galanas appears to have survived into the fifteenth century. Moreover, across the Irish Sea the similar éraic operated within Gaelic lordships well beyond the Middle Ages, ${ }^{117}$ while blood-money is found in Anglo-Irish lordships as well. ${ }^{118}$ Ireland leads us back to Scotland, where the eleventh-century 'Laws of the Brets and the Scots' (so-called) detailed the equivalent, cró $^{119}$ - which, as Wormald showed, survived loosely as late medieval and early modern 'assythment'. ${ }^{120}$

${ }^{111}$ Pardons appear on virtually every page of the 45 volumes of the Calendars of Patent Rolls covering the years 1307-1509.

${ }^{112}$ Helen Lacey, The Royal Pardon: Access to Mercy in Fourteenth-Century England (Woodbridge, 2009), 20.

${ }^{113}$ For good accounts of the fourteenth-century English system, see ibid., 1-81, and Anthony Musson, Public Order and Law Enforcement: The Local Administration of Criminal Justice, 1294-1350 (Woodbridge, 1996).

${ }^{114}$ Above, at note 97.

${ }^{115}$ Sir Frederick Pollock and Frederic William Maitland, The History of English Law before the time of Edward I (1895; 2nd edn., reissued, London 1966), ii, 483.

${ }^{116}$ Davies, 'Survival of bloodfeud', 339.

117 The best study is Neil McLeod, 'The blood-feud in medieval Ireland', in Pamela O'Neill (ed.), Between Intrusions: Britain and Ireland between the Romans and the Normans (Sydney, 2004), 114-33, which starts in the 1450 os and uses Gluckman's 'Peace in the feud'. See also Katherine Simms, From Kings to Warlords: The Changing Political Structure of Gaelic Ireland in the Later Middle Ages (Woodbridge, 1987), 89-91; K. W. Nicholls, Gaelic and Gaelicized Ireland in the Middle Ages (2nd edn., Dublin, 2003), 59-64; and Fergus Kelly, A Guide to Early Irish Law (Dublin, 1988), 125-34.

${ }^{118}$ Peter Crooks, 'Factions, feuds and noble power in the lordship of Ireland, c.1356-1496', Irish Historical Studies 35 (2007), 425-54, esp. p. 453; Nicholls, Gaelic and Gaelicized Ireland, 60-4.

${ }^{119}$ Alice Taylor, 'Leges Scocie and the lawcodes of David I, William the Lion and Alexander III', SHR 88 (2009), 207-88, at pp. 237-43, and (for text and translation) 278-9, 286-8; Patrick Wormald, 'Anglo-Saxon law and Scots law', SHR 88 (2009), 192-206.

${ }^{120}$ Wormald, 'Bloodfeud', 62-4. It was still paid in the eighteenth century, and was not formally abolished until 1996: W. David H. Sellar, 'Forethocht felony, malice aforethought and the classification of homi- 
And with respect to Scotland, whereas when 'Bloodfeud' was published it seemed exceptional, it now appears to be entirely normal. What are the general implications? Though Max Weber's concept of the modern state's 'monopoly of legitimate force' is conspicuously absent, ${ }^{121}$ the underlying concept - that the state's purpose is to uphold law and order - applies usefully to the medieval era. But what law was upheld? It involved not only enactments ('statute law'), but also traditional rules which tolerated the commonest forms of killing (in hot-blooded quarrel and self-defence) and required compensation for the victim's kin. And how was 'order' maintained? The main need was to prevent prolonged feuding, which was more achievable through pacification than punishment, since the latter could stimulate more feud. Pardons and bloodmoney were therefore crucial for medieval law-and-order mechanisms. Admittedly these varied - the 'state' is less visible in Germany, while in England, where it is most visible, the compensation requirement disappeared. As for Scotland, its system resembles France's - and both seem good examples of the late medieval approach to maintaining law and order, which evokes not Weber's monopoly of force but Michel Foucault's contention that sovereignty's fundamental attribute was the right 'to take life or let live'. ${ }^{122}$ The life-giving pardon can be called the ultimate act of state.

\section{II}

The rest of my reflections are specifically Scottish, and focus on royal remissions. Technically, these relate to crime rather than feuding, which, as the 1598 act anent feud shows, was not crime per se. ${ }^{123}$ But what was medieval crime? For Scotland, Alice Taylor answers significantly, 'we cannot continue identifying crime by the presence of royal or ... state punishment. Crime should instead be understood to denote offences that an authority put right, through the force of its own law-making'. ${ }^{124}$ Saudi Arabia, where the state plays a largely enabling role, comes to mind. ${ }^{125}$ But from the later twelfth century the Scottish crown claimed more. A charter of William I asserted that major offences - 'murder, premeditated assault, rape, arson and plunder' - belonged 'to my regality' and should be prosecuted by his 'crowner' before his justices; while his laws forbade lords from holding courts without notifying the sheriffs, and reserved the 'four

cide', in W. M. Gordon and T. D. Fergus (eds.), Legal History in the Making (London, 1991), 43-59, at p. 47.

${ }^{121}$ Weber: Political Writings, ed. Peter Lassman and Ronald Spiers (Cambridge, 1994), 310-11.

${ }^{122}$ Michel Foucault, 'Society must be defended': Lectures at the Collège de France, 1975-76, trans. David Macey (London, 2003), 240-1. See also Gauvard, 'Grâce et exécution capitale', 290: 'The judicial power of the king thus has a double nature: it is simultaneously a power of life and a power of death'.

123 RPS, 1598/6/2: it was intended to pacify feuds through compulsory royal arbitration, and also enable those against whom 'deadly crimes' had been committed in the course of the feuds to make formal accusations.

${ }^{124}$ Alice Taylor, 'Crime without punishment: Medieval Scottish law in comparative perspective', in David Bates (ed.), Anglo-Norman Studies, XXXV: Proceedings of the Battle Conference 2012 (Woodbridge, 2013), 287-304; quotation from p. 304; I am most grateful to Dr Taylor for sending me a prepublication copy.

125 Above, at note 25. 
pleas ... pertaining to his crown: namely rape, plunder, arson and murder'. ${ }^{26}$ Furthermore, the thirteenth-century 'legislation of Alexander II reveals a royal monopoly over crime' - which has obvious implications for the granting of remissions. ${ }^{127}$

Such a monopoly was never absolute, however, because (as in France) the rights of the victim of crime or his kin remained fundamental. Consequently, Scottish remissions, like French (and as in shari'a law), were always conditional on the offender giving assythment. That is clear from the first known text of a remission for killing, in an early fourteenth-century formulary:

[the king] remits our rancour against $\mathrm{T}$ de $\mathrm{C}$ for the death of $\mathrm{X}$, provided that he makes peace with the relatives and friends of $\mathrm{X}$ so that we hear no further complaint; takes him under our peace; and forbids anyone to hurt him on account of the death of $\mathrm{X}$ under pain of forfeiture, or to kill him under pain of death. ${ }^{128}$

An actual early fifteenth-century remission is similar but fuller:

Remission by Robert, Duke of Albany, Governor of Scotland, to Thomas Boyd of Kilmarnock, Robert Muir of Rowallan, etc., for the slaughter of Maurice Neilson of Dalrymple, Robert Black and Donald Young at Dalmellington, for burning their houses, for ravaging the goods and chattels of Alexander Cunningham at Badlane, and the lands of Drumcross, and for all other depredations. Provided that Thomas etc. make such peace and concord with the kin and friends of the late Maurice etc., and give such compensation for all damages, that henceforth no complaint shall be heard about this matter. Also, Thomas etc. are taken firmly into the Governor's peace: they are not to be attacked, under threat of royal forfeiture. 24 October $1409 .{ }^{129}$

Unfortunately Scottish remissions, unlike French, did not rehearse offenders' stories; but their principle was the same. So was the procedure, which (at least from the later fifteenth century) involved obtaining a royal letter that was either effective immediately, or was examined in court (usually under challenge), and if acceptable was then put into operation; but both processes depended on the opposing party issuing a 'letter of slains' certifying due satisfaction. ${ }^{130}$ In Scotland as in France, however, remissions

${ }^{126}$ RRS, ii, no. 80; Taylor, 'Leges Scocie', 211, 282-3 (LS, c.7).

${ }^{127}$ Quotation fromTaylor, 'Crime without punishment', 304; and for the implications, Cynthia J. Neville, 'Royal mercy in later medieval Scotland', Florilegium, forthcoming. I am most grateful to Professor Neville for sending me a final draft of this article, which introduces her current research project on the subject.

${ }^{128}$ Scottish Formularies, ed. A. A. M. Duncan (Stair Society, 2011), E44, giving the text of either A39 or A40 (p. 21), which are early fourteenth-century; Duncan's summary, slightly amended.

${ }^{129}$ NRS, Boyd of Kilmarnock Papers, GD8/1; my summary.

${ }^{130}$ This derives mostly from Jackson W. Armstrong, 'The justice ayre in the Border sheriffdoms, 1493- 
were strongly criticised, as in the later-fifteenth-century poem on kingship known as 'The Harp':

But of one thing all good men marvel more

When great council, with thine own consent

Has ordained strict justice no man to spare

Within short time thou changes thine intent

Sending a contrair letter incontinent

Charging of that matter may be naught

Then all the world murmurs thou art bought

And when thou gives a plain remission

In case requiring rigour of justice

But [without] goodly cause, thou offends to the crown

And forfeits both to God and thine office. ${ }^{131}$

Historians have mostly echoed such criticism, but detailed analysis gives a more complex picture.

The first reference to remissions is in the Assise Willelmi Regis: if a thief was lawfully executed and his kin killed his accuser, 'the king shall have his full right from the killers' - 'without any concord or remission unless by the advice and consent of [the victim's] kin'; and if he granted remission without their knowledge, they 'may take vengeance on those who killed their kinsman'. But only the first part (to the dash) is William I's; the rest is a late thirteenth- or early fourteenth-century amendment. ${ }^{132}$ That shows the emergence of remissions, and highlights the necessity for consent by the victim's kin and the legitimacy of vengeance killing - though perhaps only in this special case.

Formal parliamentary records begin with Robert I's legislation of 1318 , which has three relevant chapters. Because of past 'disagreements and grievances ... between the nobles', c.22 forbade 'that henceforth any person cause damage, burden or harm to another', and anyone doing so shall have 'broken the peace of the lord king', ${ }^{133}$ which looks like a (highly optimistic) ban on feuding. Also, c.5 enacted that when anyone was convicted 'of homicide, rapine, theft or other offences ... common justice be done

1498', SHR 92 (2013), 1-37, at pp. 30-3; and for slains, see Wormald, 'Bloodfeud', 62-3, 66.

${ }^{131}$ Liber Pluscardensis, 2 vols., ed. F. J. H. Skene (Edinburgh, 1877-80), i, 399-400. This chronicle was written in the early 1460 s, but survives only in copies from $1478 \times 1496$ and (apparently) 1489. The poem - the last item in the chronicle - is in only the 1489 version (ibid., i, pp. x-xii), and so may well be an addition to the text proper. Therefore it is more likely to be aimed at James III (whom the criticism fits exactly, see below, at note 145) than James II, as is usually said, e.g. by Roland Tanner, The Late Medieval Scottish Parliament: Politics and the Three Estates, 1424-1488 (East Linton, 2001), 162.

132 Taylor, 'Leges Scocie', 232-4.

133 RPS, 1318/22. 
without redemption', and c.11 that 'no-one [shall] take a redemption from a thief'- but neither provision applied to the king or to lords possessing 'liberties in such matters'. ${ }^{134}$ So lords of regality could grant remissions; but who else had been doing so, wrongfully? Perhaps earls - which would have important implications - but we cannot say. However, crown authority over remissions was now asserted.

Next, after David II came back from captivity in 1357, his 'full council' declared 'that nobody in future shall move war against his neighbours' (again anti-feud), and that the king would review past remissions by his lieutenant. ${ }^{135}$ However, royal impartiality became an issue: in 1366 'the three communities' insisted that justice should be done without favour, that judicial letters should not be revoked (as later in 'The Harp'), and that 'remissions ... should be null and void' unless compensation was accepted within a year. ${ }^{136}$ And in 1370, David had to prohibit remissions for homicides found by inquest to be by 'murder or malice aforethought' unless the general council gave approval; though he could still grant them for unpremeditated killing. ${ }^{137}$ Theoretically, that was a significant change. For William I, 'murder and premeditated assault' pertained 'to my regality', and so, by Robert I's logic, the crown could grant remissions for them; but parliament was now attempting to restrict that regality.

After Robert II succeeded David, the 1372 parliament developed the new rules, allegedly because of recent killings. Since justice 'was not as fast as expedient', in future a killer should be imprisoned while an immediate assize determined whether the homicide was 'by forethought felony or murder, or from the heat of anger, namely chaudemella'. If the former, 'justice is immediately to be done'; if the latter, 'he will have the legitimate and due delays and defences'. ${ }^{138}$ Those who committed murder or forethought killing were now to be executed at once! The new rules were draconian but exceptional, because they were to apply for just three years. And 1384 saw further law-and-order legislation. Unfortunately the homicide measures (again for three years) are lost; but the concept of forethought malice (precognita malicia) was extended to mutilation, wounding and beating. ${ }^{139}$ The next recorded legislation was under Robert

${ }^{134}$ RPS, 1318/5, 11. Note Scottish Formularies, E49 (pp. 74-5): a brieve by which the king 'following his statute issued dealing with such a case, remits his rancour' for a killing found by inquest to be in selfdefence. This, pace Duncan, can be associated with the 1318 legislation, c.5.

${ }^{135}$ RPS, 1357/11/12-13.

${ }^{136}$ Ibid., 1366/7/6, 13, my paraphrase of some problematic wording, which may have been mistranscribed: 'remissions should be null and void, nec satifiat parti infra annum a data earundem, nisi forte manifeste steterit per illos quorum interest'.

${ }^{137}$ Ibid., 1370/2/36: per murthyr vel per precogitatam maliciam. See also 1370/2/12, and Scottish Formularies, E14 (pp. 55-6): a 'brieve to the sheriff to hold an inquest into whether the bearer killed someone in a rage and not by murder or forethought felony'; this probably dates from the early 1370 , and certainly from before 1424 .

${ }^{138}$ RPS, 1372/3/6, and 7-12; Sellar, 'Forethocht felony', 48-9.

${ }^{139}$ RPS, 1384/11/1, 6-17. A whole folio is clearly missing between the preamble to c.6, and the middle of what is called c.7: see notes to c. 6 and c.7. The time limit is stated in c.17, while c.9 deals with mutilation and wounding by forethought, for which the process should proceed 'as is ordained above concerning homicide'. Much of Robert II's and Robert III's parliamentary records are missing, and what survives is mostly in problematic copies: ibid., 1384/1/1, note. 
III: the 1397 'statute of Stirling' addressing 'great and horrible destructions ... and slaughters'. No one was to 'use destructions, slaughter, reif nor burning ... under the pain of forfeiture of life and goods', and for three years offenders identified by inquest had to give securities to appear at the next justice ayre; those who could not would be executed, and those who fled would be put 'to the horn [outlawed] without remission'. ${ }^{140}$ The following year, 'to repress transgressors more sternly', all offenders were given just forty days 'to stand to law', or be outlawed; ${ }^{141}$ while in 1399 , a further amendment put victims' complaints to royal officers on the same footing as formal inquests, and the statute was extended for three more years. ${ }^{142}$

The later fourteenth-century acts demonstrate serious concern about law and order, echoing English and French measures. ${ }^{143}$ But they also demonstrate consistent, thoughtful efforts by the political elite to make the system more effective, including (ideally) limiting remissions to unpremeditated offences. That, however (as noted above), restricted royal power and grace, and so had to be convincingly justified: hence the preambles highlighting awful lawlessness, which (as with modern equivalents) can be regarded as political propaganda depicting a collapse of law and order which had to be rectified. ${ }^{144}$

The most famous instance of such propaganda is, of course, Bower's story of James I being told on his return to Scotland in 1424 about the 'thieving, dishonest conduct and plundering' in Scotland, and replying, 'If God spares me I shall see to it that the key guards the castle and the thorn bushes the cow'. ${ }^{145}$ His first enactment in 1424 was 'that firm and secure peace be ... held among all and sundry lieges and subjects of our sovereign lord the king. And that no man ... move or make war against another, under all pain that may follow by the course of common law'. ${ }^{146}$ That is nothing new, and in practice his only important innovation was to make his predecessors' three-year provisions permanent. But the lives of those guilty of forethought homicide were to be 'at the king's will', so remissions were not forbidden: James had cancelled the 1370 s restriction on royal grace. ${ }^{147}$ His other acts simply modified the 1370-99 measures, ${ }^{148}$ and minor amendments are all that can be found under his

${ }^{140}$ Ibid., 1397/1-2.

${ }^{141}$ Ibid., 1398/9.

${ }^{142}$ Ibid., 1399/1/14.

${ }^{143}$ For these, see Sellar, 'Forethocht felony', 46-6, 51-2.

${ }^{144}$ For an in-depth analysis of political propaganda relating to crime which is relevant here, see Claude Gauvard, 'Fear of crime in late medieval France', in Barbara A. Hanawalt and David Wallace (eds.), Medieval Crime and Social Control (Minneapolis, Minn., 1999), 1-48: a translation of 'De grâce especial', chapter 5 .

${ }^{145}$ Chron. Bower (Watt), viii, 323. This theme is excellently explored in Michael Brown, 'James I', in Michael Brown and Roland Tanner (eds.), Scottish Kingship, 1306-1542: Essays in Honour of Norman Macdougall (Edinburgh, 2008), 155-78, at pp. 157-64, and p. 175 for how James's harsh administration of government, especially justice, backfired fatally in 1437 .

146 RPS, 1424/2a.

${ }^{147}$ Ibid., 1426/10.

${ }^{148}$ Compare RPS, $1424 / 5$ with $1397 / 1 ; 1425 / 3 / 15$ with $1397 / 2 ; 1426 / 10$ with $1372 / 3 / 6,1398 / 9$, and 1399/1/4; 1432/3/2 with 1372/3/6; and 1432/3/6-7 with 1398/10. 
successors. ${ }^{149}$ But in 1473 parliament exhorted James III 'to close his hands for remissions and respites'; ${ }^{150}$ in 1477 , because 'the greatest reason' for the frequency of slaughter 'is the easy granting of the king's grace in pardons', forgiveness 'for any kind of slaughter' was suspended for the next three years; ${ }^{151}$ and there were three similar acts in 1484, 1485 and $1487 .{ }^{152}$ This is worse than the pressure on David II, and surely reflects a specific problem with James III (as probably reflected in 'The Harp') - which he may have justified in terms of royal power to 'let live' through acts of mercy. ${ }^{153}$

In contrast, under James IV - who has the best law-and-order reputation of any late medieval Scottish king - the legislation has no mention of (and hence concern about) remissions until 1504, when, because of 'great slaughter ... and the reasons for it in the assurance and belief of getting swift remissions', he agreed to prohibit them 'for slaughter committed as premeditated felony' until decided otherwise. ${ }^{154}$ This parliament, however, was held in response to specific defiance from parts of the Highlands and the West, and both the preamble and the act (with its ban on mercy for deliberate killing) can be seen as political statements. That said, the act - which echoes criticisms of his father - has been seen as complaining about James using remissions to raise money. ${ }^{155}$ These were certainly lucrative: for instance in 1495 Hugh Rose of Kilravock and William Munro of Foulis (plus accomplices) paid £233.6s.8d. and £8o respectively for remissions for killing Walter Gawane. ${ }^{156}$ But so long as the crown ensured that remissions did bring assythment and pacification (which James III probably did not do), then to view them chiefly from a fiscal standpoint is distorting. As with early medieval wergeld or cró and modern fines, the exaction of money was primarily punitive; royal remissions for serious crimes were not cheap, while the victim's kin had to be compensated, too.

More significantly, the act banned only remissions for homicide by forethought. The preamble suggests such killings were widespread, but is that correct? For James

${ }^{149}$ Ibid., 1469/25; 1471/5/3; 1484/2/33; 1485/5/10; 1487/10/8-9; 1488/1/22.

${ }^{150}$ Ibid., 1473/7/10. A respite was a conditional remission, limited to a number of years.

${ }^{151}$ Ibid., 1478/6/80: discussed (and redated) in Tanner, Late Medieval Scottish Parliament, 214-15, along with a 1477 privy seal letter to the sheriff of Edinburgh ordering public proclamation that there would be no 'respite or remission for slaughter committed of forethought felony' - a narrower definition than in the statute.

${ }^{152}$ RPS, 1484/2/34; 1485/5/10; 1487/10/5.

153 Tanner, Late Medieval Scottish Parliament, 215, 251, 254-6; Norman Macdougall, James III (2nd edn., Edinburgh, 2009), 141-2, and p. 274 for the story of how James, accompanied by the papal legate and Bishop Elphinstone, pardoned a condemned aristocratic murderer with the words 'let mercy prevail' - to Elphinstone's approval. This apocryphal story may have been aimed against parliament's disapproval of James's remissions. For more on the story, see Alasdair A. MacDonald, 'James III, kingship and contested reputation', Chapter 11 in this volume.

154 RPS, 1504/3/108; also, more briefly, 1504/3/25.

155 E.g. by Norman Macdougall, James IV (Edinburgh, 1989), 164; Ranald Nicholson, Scotland: The Later Middle Ages (Edinburgh, 1974), 570.

${ }^{156} T A, \mathrm{i}, 210$. Two years later Rose received a remission for himself and eleven others, for the cruel killing of Gawane and three others in the chanonry at Fortrose: RSS, i, no. 166. It is unclear whether this was linked to the 1495 payment, or whether there was a new transaction because of the other three mortalities. 
IV, the Privy Seal Register survives, and so all the registered remissions that were formally registered can be studied - though here only a brief analysis is possible. In all, 581 remissions and temporary respites were registered. The breakdown of the most serious offence mentioned in each of them is: 249 remissions or respites for homicide; ninety-seven for forethought felony; 114 for defying the crown (mostly by rebelling, helping rebels and outlaws, refusing to serve in the army, and abusing sheriffs); fiftyfour for reif or robbery (mostly of livestock); forty for arson, plunder and other 'oppression' (damage to property); five for rape; fourteen for theft; and eight for 'theftwise' damaging the goods of the victim when lying with his wife (which must have meant stealing or damaging the husband's sexual rights over his wife, thus making adultery criminal and entitling the husband to assythment). All the offences except theft and adultery usually involved violence and could be associated with feud, but here my focus is on homicide and forethought felony. ${ }^{157}$

It should be noted, however, that 'forethought felony' per se did not automatically indicate killing: its general usage shows it was a wider concept, applicable to any premeditated violence. That is demonstrated by the remission granted to Andrew, Thomas and John Hunter in September 1498, 'for the slaughter of the late (umquhile) Thomas Blackford, and for the forethought felony done upon the said Thomas, his wife, bairns and servants': ${ }^{158}$ clearly Thomas, his wife, children and servants had suffered a premeditated attack, but only Thomas had been killed, perhaps by accident. More generally, when a person is said to have been killed, they are invariably described as 'late', which is never found in forethought remissions unless a killing is also recorded; and whereas with remissions for homicide all other offences are normally included as well, with remissions for forethought offences that are not said to involve a killing, homicide is always specifically excluded. ${ }^{159}$

As for the 249 instances of actual homicide, remarkably few killings are said to be for forethought: only nine before the 1504 act, one in 1507 and two in $1510-11{ }^{160}$ There were fifteen remissions for 'cruel homicide', presumably horrific or excessive wounding ${ }^{161}$ and twenty-eight for homicide 'by suddenty' or the like, in most cases no doubt

${ }^{157}$ Found within RSS, i, pp. 1-386; counting only the most serious offences recorded in each remission or respite (note that a single offence could generate several remissions, if several individuals were involved). Because of this methodology, my figures differ from those given in Nicholson, Scotland, 569, Macdougall, James IV, 164, and Leslie J. Macfarlane, William Elphinstone and the Kingdom of Scotland, 1413-1514 (Aberdeen, 1985), 411-12, 436 (in which, incidentally, reif and theft seem to have been merged). A full-scale analysis of the material is planned by Cynthia Neville; see above, note 127 .

${ }^{158}$ RSS, i, no. 251.

${ }^{159}$ Nicholson, Macdougall and Macfarlane do not mention this important point with respect to their remission analyses. But, more significantly, Armstrong, 'Justice ayre', 26-9, counts all mentions of forethought felony as homicide, which, unfortunately, seriously distorts that part of his analysis and argument. For the 1384 legislation, RPS, 1384/11/9, and above, at note 139.

${ }^{160} R S S$, i, nos. 16, 106, 109, 163, 251, 307, 412, 690, 825, 1410, 1991, 2193. The 1504 act was probably cancelled in the 1509 parliament, but most of its legislation is lost: Macdougall, James IV, 190-1.

${ }^{161} R S S$, i, nos. 117, 127, 166, 412, 584, 676, 718-20, 918, 1410, 1572, 1980, 2204, 2259. 
due to outbursts of rage ${ }^{162}$ - as with John Thowles's remission for killing Alexander Meill 'suddenly with a blow from a staff, namely a golf club' ${ }^{163}$ However, the form of homicide is not categorised in the other 194 instances. Some, like the killing of a child by the cast of a stone at a dog, ${ }^{164}$ would have been accidental. But a broader explanation can be suggested. Since the 1370 s there had been formal inquests into whether X killed $\mathrm{Y}$ 'by forethought felony or not'. ${ }^{165}$ Any homicides not clearly caused by accident or rage should have been investigated, and those which inquests found not to be by forethought were probably recorded simply as homicide, ${ }^{166}$ with no qualification (including many cases of self-defence, which the remissions never mention). In addition, the well-known propensity of medieval juries to favour the defendant would also help to explain why forethought verdicts were so scarce. ${ }^{167}$

Furthermore, it was probably easy and safe to commit non-forethought homicide deliberately. Consider late medieval Scotland's two most notorious killings. When James II summoned the eighth earl of Douglas to Stirling in February 1452, did he seriously expect him to break the Douglas-Crawford-Ross bond? According to the 'Auchinleck Chronicle', when Douglas said (probably vehemently and certainly insultingly) 'he might not nor would not', James called him 'false traitor' and 'leapt suddenly to him with a knife'. James must have expected that outcome - but technically it was excusable homicide 'by suddenty', though Douglas's brother understandably called it foul slaughter. ${ }^{168}$ Similarly, when in February 1306 Robert Bruce set out for his fateful meeting with John Comyn in the Greyfriars church, Dumfries, did he seriously believe that they would reach an amicable agreement? I think not, and suggest that he anticipated and quite probably engineered a hot-blooded quarrel in which Comyn could be killed without overt premeditation. ${ }^{169}$ Irrespective of whether that is correct in these cases, the main point is that by creating a situation in which a hot-blooded quarrel was inevitable, an enemy could be killed without committing forethought felony.

Also, when rival lords' followings encountered each other, tensions could easily escalate into lethal violence, as Romeo and Juliet illustrates, and as at Monzievaird in 1489, when a long-running quarrel flared up and led to Drummonds setting the local

${ }^{162}$ Ibid., nos. 66, 288, 325, 421, 489, 522, 610, 679, 680, 696, 764, 803, 840, 929, 1123, 1181, 1296, 1547, 1581, 1595, 1617, 1697, 1726, 1746, 1802, 1992, 2004, 2194 (including a few deaths caused by 'negligence').

163 '... pro interfectione quondam Alexandri Meill ex subito per ictum baculi, viz golf club, commissa': ibid., no. 1547.

${ }^{164}$ Ibid., no. 83 .

${ }^{165}$ Above, at note 137.

${ }^{166}$ I.e. the 'simple homicide' of Regiam Majestatem: below, at note 179.

${ }^{167}$ Also, in 18 instances remissions were granted to men who had been 'put to the horn' or had fled to England, in which case formal inquests were presumably unnecessary: $R S S$, i, nos. 37, 69, 86, 90, 104, 108, 110, 113, 117, 375, 665, 696, 1301, 1331, 1361, 1414, 1578, 1597.

${ }^{168}$ Christine McGladdery, James II (Edinburgh, 1990), 165; now best discussed in Christine McGladdery, 'James II (1437-1460)', in Brown and Tanner (eds.), Scottish Kingship, 179-208, at pp. 191-5. However, pace McGladdery, James II, 66-70, this was not murder in the contemporary sense; see below, after note 180. For the aftermath of the killing, see Michael Brown, 'The Lanark Bond', Chapter 10 in this volume.

${ }^{169}$ Alexander Grant, 'The death of John Comyn: what was going on?', SHR 86 (2007), 176-224. 
church on fire with twenty Murrays inside. On the other hand, with this atrocity powerful state action was taken, not so much by the young James IV as by his council. ${ }^{170}$ That illustrates the same collective desire to maintain order as in the parliamentary legislation: the collective-versus-individual pressures promoting 'peace in the feud' were operating within 'the justice of the state'. And eleven years later, 'for heartliness ... amongst them', the Drummond and Murray lords received royal letters 'remitting to their kin and friends ... all actions and crimes of the burning of the kirk of Monzievaird and slaughter of the king's lieges'. ${ }^{171}$ Pacification of feud was always the ideal, and from the crown's standpoint the remission system was as important for achieving it as the formal 'justice of the state'.

That said, aristocratic feuding is not very visible in the privy seal register. Only twenty-four remissions or respites for homicide went to certain or probable members of the landed classes. Cuthbert Cunningham, earl of Glencairn is the greatest, but his remissions in 1508 for non-lethal forethought violence and in 1511 for killing Andrew McFarlane in Bute are not obviously connected to his long-running feud with the earl of Eglinton. ${ }^{172}$ Other leading figures who had homicide remissions or respites included William Gordon son of the earl of Huntly, Archibald Ogilvie son of Lord Airlie, David Hume of Wedderburn, Hugh Rose of Kilravock, Patrick Dunbar son of the lord of Kilconquhar, William son of Matthew Wallace of Craigie, and Andrew Blackadder of that ilk, who killed two men and wounded three 'near the king's palace while the king was in residence'. ${ }^{173}$ But the list is short, and most of the other twenty-four are only minor lairds.

Twenty-four is just under a tenth of the total: higher, surely, than the landed classes' share of the population, but roughly the same proportion as Gauvard found in France. ${ }^{174}$ Also, hardly anyone received remissions for more than one killing, and there is only one instance (discussed below) of a killer being killed himself. ${ }^{175}$ The James IV remissions and respites, in other words, give virtually no evidence of the chains of titfor-tat homicide that are usually associated with feuds. That may simply be a function of the way the documents were written; had they included the killers' narratives, the conclusion might be different. But the absence of tit-for-tat killing is also a feature (though not quite so extreme) of the French remissions. As said already, Gauvard attributed that to a crown policy of accepting that it could not prevent fatal quarrels

${ }^{170}$ Macdougall, James IV, 83-4; Boardman, 'Politics and the Feud', 288-300.

${ }^{171}$ RSS, i, no. 843 .

${ }^{172}$ Ibid., nos. 360, 2323. Also in 1511, he obtained remissions for homicide by some of his men, and for his son who had sheltered outlaws: ibid., nos. 2212, 2225, 2324. For the feud, Macdougall, James IV, 936, 101, 152-4, 187-8; Boardman, 'Politics and the Feud', 171-7, 261-88.

${ }^{173}$ RSS, i, nos. 72 (Ogilvie), 166 (Rose), 227 (Dunbar), 412 (Blackadder), 428 (Gordon), 654 (Hume), 949 (Wallace). In addition to obvious figures like these I have counted anyone who was described as 'of' a territory. The other references are ibid., nos. 35, 39, 83, 223, 351, 371, 427, 461, 625, 721, 775, 1561, 1578, 1644, 1969, 2183.

${ }^{174}$ She gives 6 per cent overall, but also shows that the proportion of homicides committed by nobles and esquires was much higher than for other crimes: Gauvard, 'De grâce especial', 74, 528-36.

175 Below, note 178. 
from breaking out in all ranks of society - but that it could, through giving letters of remission to the killers so long as the victims' families were compensated, significantly reduce the likelihood of long-term feud, such as is found in Albania. ${ }^{176}$ The evidence of the Scottish remissions in James IV's privy seal register, although a much smaller sample, indicates exactly the same conclusion - which puts Scotland beside France on Wormald's spectrum. Killing in quarrels was part of human nature, and late medieval Scotland's state machinery could not prevent it; but in normal circumstances it could stifle most potential feuds, and limit the duration of those that did break out. It did so, essentially, through the use of remissions - which could be described as harnessing the justice of the feud to serve the justice of the state.

\section{III}

However, there is a final point. Nowadays, under Scots law, all the forethought killings and many of the others would be murder. ${ }^{177}$ One of James IV's remissions and respites for forethought killing is actually for murder: 'A respite to Patrick McCulloch, for ... the murder and slaughter of the late Archibald McCulloch of Ardwell, committed ... upon forethought felony, under silence of night'. ${ }^{178}$ The 'silence of night' makes it different, in accordance with the definitions in late medieval Scotland's main legal text, Regiam Majestatem: 'There are two kinds of homicide. The first is murder, which is homicide secretly perpetrated without the knowledge of anyone except the assailant and his accomplices ... The second kind of homicide is called simple homicide'. ${ }^{179}$ Thus secrecy is the issue - which includes killing at night.

That is not just Scottish: 'as is well known, the word "murder" is cognate with Germanic "mord” and Scandinavian "morð” signifying a secret killing' ${ }^{180}$ Regiam Majestatem was copying the twelfth-century English text, 'Glanvill', ${ }^{181}$ while Philippe

176 Above, at notes 33 and 91.

177 'The classic definition of murder [is] "any wilful act causing the destruction of life, whether intended to kill or displaying such wicked recklessness as to imply a disposition depraved enough to be [intended]"': Sellar, 'Forethocht felony', 44, quoting John Hay Macdonald, A Practical Treatise on the Criminal Law of Scotland (5th edn., Edinburgh, 1948), 89.

${ }^{178}$ RSS, i, no. 163, dated 17 Nov. 1497: one of the few instances of killing within a single kin. But Patrick did not survive for long: by 2 June 1498 he himself had been killed, for which his killers got respite and eventually a full remission: ibid., nos. 227,1561 . This is the only mention in the register of the killer being killed himself.

${ }^{179}$ Regiam Majestatem and Quoniam Attachiamenta, ed. and trans. T. M. Cooper (Stair Society, 1947), 253-4.

${ }^{180}$ Sellar, 'Forethocht felony', 47; see also Taylor, 'Crime without punishment', esp. 295. But 'secret killing' is too narrow a definition: in Anglo-Saxon England 'it referred ... to particularly dishonourable killings, perhaps involving secrecy in some form or even an attempt to hide the victim's body' (Lambert, 'Theft, homicide and crime'); and $O E D$, s.v. 'murder': 'In old English the word could be applied to any homicide that was strongly reprobated ... more strictly, however, it denoted secret murder'. It is best, therefore, to regard it as an outrageous, essentially unpardonable crime - of which secret killing was the typical example.

${ }^{181}$ Tractatus de legibus et consuetudinibus regni Anglie qui Glanvill vocatur, ed. G. D. G. Hall (London, 1965), 174-6 (xiv, c.3). 
de Beaumanoir's later thirteenth-century Coutumes state that 'murder is when anyone kills anyone else or has them killed by premeditation between sunset and sunrise, or under truce or assurance'. All three contrast murder and homicide; but with Regiam and 'Glanvill' the distinction is obviously between secret and open killing; while for Beaumanoir homicide is simply killing in hot blood (chaude mellee), which blurs the issue. $^{182}$ But by Beaumanoir's time, 'premeditated malice' and 'wrath' were being distinguished in England, too, and in the fourteenth century premeditation eventually came into a statute of 1390 forbidding pardons 'for murder [and] homicide occasioned by ... malice aforethought'. ${ }^{183}$ Similarly but earlier, a French ordinance of 1356 banned royal remissions for 'murders and mutilations made by premeditation and evil will'. ${ }^{184}$ These straddle the Scottish acts of 1370 and 1372, which also restricted remissions, and made a distinction between murder and forethought felony on the one hand and (echoing Beaumanoir) chaudmella or hot-blooded killing on the other. ${ }^{185}$ Legal minds in all three countries were working in the same direction.

In fifteenth-century France and England, however, murder became more general, encompassing premeditated killing just as nowadays. ${ }^{186}$ Scottish fifteenthcentury legislation shows a similar blurring, but in the opposite direction: from James I on, the acts mention only 'forethought felony' and 'sudden chaudmella', dropping murder. That might support Sellar's argument about murder being incorporated within forethought felony in the 1370 - and it could be regarded as a sub-category of the latter in Patrick McCulloch's respite. On the other hand, as we have seen, forethought felony covered more than killing, while murder was still distinct from slaughter because it was committed at night. Moreover, the Border ayres studied by Armstrong had a case of 'forethought felony by means of murder' and another of 'murder [and] killing' - 'both suggestive of secret killing, one with premeditation, the other without'. ${ }^{187}$ Thus I would argue that in Scotland the concept of murder retained its special restricted meaning at least until the end of the fifteenth century - and perhaps beyond, given the definition in Skene's De Verborum Significatione of 1597:

MURTHURUM, whereof of some is called private, that is manslaughter, whereof the author is unknown, whereof the inquisition belongs to the crowner; as where a person is found slain, or drowned, in any place or water. Other is

${ }^{182}$ Philippe de Beaumanoir, Coutumes de Beauvaisis, 2 vols., ed. Amédée Salmon (Paris, 1899-1900), i, nos. 825,828 .

${ }^{183}$ F. W. Maitland, 'The early history of malice aforethought', in his Collected Papers, 3 vols., ed. H. A. L. Fisher (Cambridge, 1911), i, 304-28, at pp. 307-9 for a case in 1270; T. A. Green, 'The jury and the English law of homicide', Michigan Law Review 74 (1975-6), 413-72, at pp. 457-72; 'Richard II: 1390, January', ed. Chris Given-Wilson, in The Parliament Rolls of Medieval England, 16 vols., ed. Chris Given-Wilson et al. (Woodbridge, 2005), vii, 127-90, at p. 155 (c.36).

${ }^{184}$ Ordonnances des Roys de France de la Troisième Race, vol. III (Paris, 1732), 128-9.

${ }^{185}$ Above, at note 138 . Note that I read the 1370 and 1372 acts differently from Sellar, 'Forethocht felony', 47.

${ }^{186}$ Gauvard, 'De grâce especial', 798-806; Green, 'Jury and law of homicide', 469-72.

${ }^{187}$ Armstrong, 'Justice ayre', 27. 
public committed by forethought felony. And murder is committed by forethought felony and not by suddenty. ${ }^{188}$

Skene was following Regiam Majestatem, but glossing it for his own time; and while murder comes under forethought felony, it is still non-public, with unknown perpetrators - in other words secret.

In a sense, that concept of murder survives today, in crime fiction: there would be no detective novels if all killings were public! Not knowing 'whodunnit', was, of course, crucial in the worst of Scotland's political killings, that of Henry Stewart Lord Darnley, the king-consort - which was certainly murder. And in ordinary life there were no doubt many occasions when a body was found, and the questions had to be asked: had the deceased been killed, was the killing deliberate, and who was responsible? But in the past, if there was a suspect, one popular solution was the process of 'cruentation': he was brought before the corpse, which, it was believed, would bleed or speak out if touched by its murderer. An echo of this is found in the case of Sir James Standsfield, who was found dead, apparently drowned, in winter 1687-8; because his son would not let the body be viewed, he became suspect, and was eventually tried for murder. ${ }^{189}$ Earlier, the practice had been common in both Britain and France: ${ }^{190}$ so, whatever the legal terminology, 'secret' killing was different and special. The most famous illustration of that is in Chaucer's 'Nun's Priest's Tale': two friends stayed in a tavern, and one dreamed that the other was being murdered; next morning, when told his friend had left, he remembered the dream and found the body: 'murder will out'. ${ }^{191}$

In addition to obvious shock, two factors surely made secret killing so awful. First, whereas open revenge killing would be presented and understood in terms of honourable reaction to insult or the like, a secret killer was a dishonourable coward. And, even worse, his victim's kin would find it hard to achieve closure through either compensation or revenge - and they might even attack the wrong person in trying. Consequently, the secret killer was deliberately rejecting his society's pacification mechanisms. Thus when, according to Bower, Roger Kirkpatrick was killed by his guest Sir James Lindsay 'after the wine had been pleasurably drained', and Lindsay then fled on horseback but did not cover more than three miles, we might blame alcohol and think that peace could still be made. Instead, Bower relates, David II immediately held an assize which put Lindsay to death - as much, it seems, for running away (under

\footnotetext{
${ }^{188}$ Sir John Skene, De Verborum Significatione (Edinburgh, 1597), s.v.

${ }^{189}$ Rab Houston, 'Scotland's coroners: sudden death and the office of coroner in North Britain from the twelfth to the nineteenth centuries' (forthcoming), at note 8.

${ }^{190}$ Malcolm Gaskill, 'Reporting murder: fiction in the archives in early modern England', Social History 23 (1998), 1-30; Gauvard, 'De grâce especial', 179-89.

191 Geoffrey Chaucer, 'The Nun's Priest's Tale', in The Riverside Chaucer, ed. Larry D. Benson (3rd edn., Oxford, 1988), 253-61, at pp. 255-6 (lines 2984-3063).
} 
cover of night) as for the actual deed, which though presumably hot-blooded was turned into murder. ${ }^{192}$

Now, as David II's role in this case indicates, if secret killing negated feud justice, then the justice of the state had to step in - which may be a major reason for 'the rise of the state'. But that did not mean the king taking over from the kin. In the medieval world's main model for government, the Old Testament, the Jewish people were all descended from Abraham, whose lineage went through King David to Jesus Christ. David and his successors were thus heads of the Jewish kindred - as were Cerdic and his descendants for the Saxons, and so on. For Alba and Scotland, Dauvit Broun and others have shown, 'the Pictish antecedents of Scottish kingship are ... proclaimed in the eleventh-century text Lebor Bretnach', which includes the legend of Cruithne (Pict) and his seven sons who took 'the north of the island of Britain'. Each son in turn succeeded Cruithne - and their names correspond to seven provinces, each theoretically inhabited by the descendants of one of the sons. The story was probably created in the eighth century, and survived into the twelfth and beyond. ${ }^{193}$ Its message, of course, was that all the people of all the provinces of Alba descended from Cruithne so that Cruithne's successor as king was head of the kin of the whole of Alba and later Scotland. Therefore, if the justice of the state was the justice of the king, that made it the justice of the overall head of the entire Scottish kindred. And from that conceptual standpoint, the king's justice could not be distinguished from the kin's justice. My final reflection on Wormald's bloodfeud and the interaction between the justice of the feud and the justice of the state, therefore, is that there is no dichotomy between them: they are interlinked aspects of the same whole. ${ }^{194}$

${ }^{192}$ Chron. Bower (Watt), vii, 309. Also, Bower tells us that Lindsay and Kirkpatrick were both sons of men who helped Robert Bruce kill John Comyn, and that the sons were being punished for the sins of the fathers (p. 311).

193 Dauvit Broun, Scottish Independence and the Idea of Britain: From the Picts to Alexander III (Edinburgh, 2007), 55-7, 76-80.

${ }^{194}$ My warmest thanks to Dauvit Broun, Stewart Carroll, Rab Houston, Alison Grant, Hector MacQueen, Cynthia Neville, Alex Metcalfe, David Sellar and Alice Taylor for their invaluable help and advice; to Steve Boardman and Julian Goodare for their patience as well; and of course more generally to Jenny Wormald, for all her support, encouragement and constructive chivvying over more than 40 years and for forgiving my question in our very first conversation: 'what were bonds of manrent, and why do they matter'? 